\title{
Erratum to: Coloring the College Pathway: A More Culturally Responsive Approach to College Readiness and Access for Students of Color in Secondary Schools
}

\author{
Anjalé D. Welton • Melissa A. Martinez
}

Published online: 29 May 2014

(C) Springer Science+Business Media New York 2014

\section{Erratum to: Urban Rev \\ DOI 10.1007/s11256-013-0252-7}

The term "achievement debt" appears twice in the text:

1. The first line of the 9th page of the article-..."between these student groups as the 'achievement debt' (under the heading "Asserting a Culturally Responsive Pathway to College")

2. On the 12th page of the article-"Similar to the achievement debt identified by Ladson-Billings (2006)"... (just after the subheading The College Readiness Debt)

Both instances should read "educational debt."

The online version of the original article can be found under doi:10.1007/s11256-013-0252-7.

\section{A. D. Welton $(\bowtie)$}

Education Policy, Organization, and Leadership, University of Illinois at Urbana-Champaign, 1310 S. 6th St. MC 708, Champaign, IL 61820, USA

e-mail: ajwelton@illinois.edu

\section{A. Martinez}

Education and Community Leadership, Texas State University-San Marcos, 601 University Drive, ASB South 322, San Marcos, TX 78666, USA 